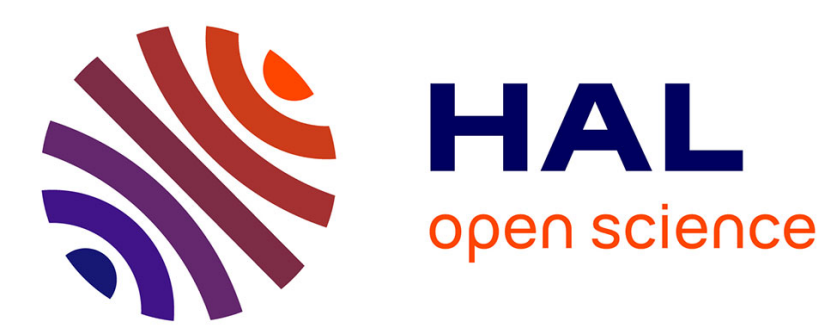

\title{
Biology Teacher Education in Flanders and in France Results of an Erasmus Staff Mobility Teaching Assignment
}

\author{
Bart Hempen
}

\section{- To cite this version:}

Bart Hempen. Biology Teacher Education in Flanders and in France Results of an Erasmus Staff Mobility Teaching Assignment. Contextes et Didactiques, 2015, Didactiques des sciences en contexte, 5. hal-02050156

\section{HAL Id: hal-02050156 https://hal.univ-antilles.fr/hal-02050156}

Submitted on 26 Feb 2019

HAL is a multi-disciplinary open access archive for the deposit and dissemination of scientific research documents, whether they are published or not. The documents may come from teaching and research institutions in France or abroad, or from public or private research centers.
L'archive ouverte pluridisciplinaire HAL, est destinée au dépôt et à la diffusion de documents scientifiques de niveau recherche, publiés ou non, émanant des établissements d'enseignement et de recherche français ou étrangers, des laboratoires publics ou privés. 


\title{
Biology Teacher Education in Flanders and in France Results of an Erasmus Staff Mobility Teaching Assignment
}

\author{
Bart HEMPEN \\ Odisee Hogeschool Brussel, Belgique
}

\section{Résumé}

Ayant été un enseignant éducateur de biologie ainsi que d'un coordonnateur Erasmus pour plus d'une décennie, le contenu de cet article combine les deux professions de l'auteur. Premièrement, cet article met l'accent sur les avantages du programme Erasmus pour le personnel des établissements d'enseignement supérieur en Europe, en décrivant une expérience personnelle de l'auteur: une visite d'étude à l'Institut Universitaire de Formation des Maîtres en Guadeloupe. Par la suite, l'auteur compare le contenu de l'enseignement de la biologie et la formation professeur de biologie en Flandre et en France. Cette comparaison est le résultat de une visite d'étude.

\section{Mots-clés}

Biologie, formation des maîtres, curriculum, Flandres, France.

\begin{abstract}
Having been a biology teacher educator as well as an Erasmus co-ordinator for more than a decade, the content of this article combines both professions of the author. First this article focuses on the benefits of the Erasmus programme for staff of higher education institutes in Europe, by describing a personal experience of the author: a study visit to the Institute Universitaire de Formation des Maitres in Guadeloupe. Thereafter, the author compares the biology teacher education and subject content taught in Flanders and in France. This comparison resulted from this study visit.
\end{abstract}

\section{Keywords}

Biology, teacher training, curriculum, Flandres, France. 


\section{LLP-ERASMUS Staff Mobility Teaching Assignments}

Since 1987 university students can obtain a grant from the Erasmus (European Region Action Scheme for the Mobility of University Students) Programme, the operational framework for the European Commission's (EC) initiatives in higher education. This programme opened up to university teaching staff in 1997.

In 1994 the Erasmus Programme was incorporated into the Socrates I programme. This programme ended on 31 December 1999 and was replaced by the Socrates II Programme (ended 31 December 2006), which in turn was replaced by the current Lifelong Learning Programme (LLP) 2007-2013, that will end on 31 December 2013.

Since the existence of the LLP-ERASMUS higher education staff mobility exists for both teaching and training. Only higher education institutions that hold an ERASMUS University Charter are entitled to participate in LLP-ERASMUS. Teaching takes place at higher education institutions that also holds an ERASMUS University Charter. Both institutions have signed an inter-institutional agreement, agreeing to accept incoming teaching staff from each other.

Staff mobility for training saw the light on 1 January 2007 when the LLP started. Training of higher education staff can be organised both by higher education institutes and by enterprises. This article will not focus on training but on teaching staff mobility under LLP-ERASMUS.

Staff mobility for teaching enables teaching staff of higher education institutions to spend a period of teaching abroad, lasting between 1 day (or at least 5 teaching hours) and 6 weeks at a higher education institution in another LLP-ERASMUS participating country. The EC strongly recommends a minimum duration of 5 working days to provide a meaningful contribution to the teaching programme and international life at the host institution.

LLP-ERASMUS Staff Mobility Teaching Assignments (STA) are organised in order to motivate teaching staff to become mobile, to promote exchange of expertise and experience on pedagogical methods, to broaden and enrich the content of their courses, and to create links between the higher education institutions involved, on one hand. Whereas on the other hand STA also enable students not having the possibility to go abroad, to benefit at home from the knowledge and expertise of teaching staff from higher education institutions from another European country. The teaching activities should be integrated into the curricula of the host institution. Therefore the teaching programme by the visiting teacher must be agreed in advance by all parties.

Teaching staff interested in STA can apply for a mobility grant through the international office of their home institution. The grant is provided to cover travel costs and to contribute to subsistence costs. Table 1 shows the number of teachers that received an ERASMUS grant for STA. The average grant amount and the duration of the mobility period are also indicated. 


\begin{tabular}{|c|c|c|c|}
\hline Academic year & $\begin{array}{c}\text { Total number of } \\
\text { teachers }\end{array}$ & $\begin{array}{c}\text { Average grant } \\
\text { (in } \boldsymbol{\epsilon} \text { ) }\end{array}$ & $\begin{array}{c}\text { Average duration } \\
\text { (days) }\end{array}$ \\
\hline $\mathbf{1 9 9 7 / 9 8}$ & 7.797 & 842 & $\mathrm{~N} / \mathrm{A}$ \\
\hline $\mathbf{1 9 9 8} / \mathbf{9 9}$ & 10.605 & 763 & $\mathrm{~N} / \mathrm{A}$ \\
\hline $\mathbf{1 9 9 9 / 0 0}$ & 12.465 & 724 & $\mathrm{~N} / \mathrm{A}$ \\
\hline $\mathbf{2 0 0 0 / 0 1}$ & 14.356 & 615 & 6,9 \\
\hline $\mathbf{2 0 0 1 / 0 2}$ & 15.872 & 594 & 6,8 \\
\hline $\mathbf{2 0 0 2} / \mathbf{0 3}$ & 16.934 & 594 & 6,7 \\
\hline $\mathbf{2 0 0 3} / \mathbf{0 4}$ & 18.496 & 575 & 6,4 \\
\hline $\mathbf{2 0 0 4 / 0 5}$ & 20.877 & 577 & 6,2 \\
\hline $\mathbf{2 0 0 5} / \mathbf{0 6}$ & 23.462 & 597 & 6,4 \\
\hline $\mathbf{2 0 0 6} / \mathbf{0 7}$ & 25.808 & 583 & 6,3 \\
\hline $\mathbf{2 0 0 7 / 0 8}$ & 27.157 & 648 & 5,5 \\
\hline $\mathbf{2 0 0 8} / \mathbf{0 9}$ & 36.388 & $\mathrm{~N} / \mathrm{A}$ & $\mathrm{N} / \mathrm{A}$ \\
\hline Total & $\mathbf{2 3 0 . 2 1 7}$ & & \\
\hline
\end{tabular}

Table 1 : ERASMUS teacher mobility 1997/1998 - 2008/2009 (adapted from (2))

It is obvious that the number of STA increases with time, whereas the average grant and duration decreased slightly. The growing popularity may be partly explained by the importance accreditation committees give to the internationalisation phenomenon. These committees measure the quality of education programmes offered by an institute of higher education, and decide about its existence.

\section{Going abroad}

In the beginning of 2007 after the LLP was born many sessions were organised by the EC and its national agencies that distribute the LLP grants, informing staff of international offices about the possibilities LLP offers. Having been an Erasmus co-ordinator since 1999 I was not expecting to gather a lot of new information. However, the map of countries a teacher can travel to got my attention.

Currently this map would indicate that a teacher willing to go abroad to teach at a LLP ERASMUS partner institution, can travel to 32 countries outside of his/her home country. Thus, 33 countries currently participate in LLP-ERASMUS: all 27 EU member states, as well as Croatia, Iceland, Liechtenstein, (the former Yugoslav Republic of) Macedonia, Norway and Turkey (1). At least the sending or the receiving country must be an EU Member State.

One should expect to be shown a map of Europe, but during the information session of the EC in the beginning of 2007, the EC staff member confronted its audience with a map of the world. The reason for this was simple, LLP ERASMUS actions can not only be undertaken in the 33 countries mentioned above, but in its in overseas countries and territories as well, as defined by Council Decision 2001/822/EC (3). Thanks to this decision a teacher can also perform the LLP-ERASMUS Staff Mobility Teaching Assignment in the overseas French departments, i.e. Guadeloupe, Guyana, Martinique and Réunion, in the Spanish Canary Islands, and in the Portuguese Azores and Madeira. 
Enriched with this knowhow, Hogeschool-Universiteit Brussel (HUB) contacted the Institutional Erasmus Co-ordinator of the Universite des Antilles et de la Guyane (UAG) based in Pointe-à-Pitre, Guadeloupe. In 2008, after discovering that both institutions had several education programmes in common, an inter-institutional agreement was signed for the exchange of teaching staff between both institutions' school of education.

\section{HUB meets UAG}

In 2010 biology teacher educators was the first teaching staff to benefit from the 2008 interinstitutional agreement between HUB and UAG. The author of this article, a biology teacher educator from HUB's Lerarenopleiding ( $=$ Teacher Education) visited the Institut Universitaire de Formation des Maîtres (= IUFM or University Institution of Teacher Education), at that moment about to fully integrate and already associated with the UAG.

On forehand a teaching programme was elaborated indicating the following goals: comparing teacher education in Flanders and in France, especially focussing on the training of biology teachers. The teaching programme was integrated into the curricula of the IUFM teacher education students that were about to finish their studies.

During the LLP-ERASMUS Staff Mobility Teaching Assignment the Belgian teacher educator explained how teacher education takes place in Flanders, while the Colleagues from Guadeloupe explained how teacher education in France works. Both parties focused on the teacher education of teachers teaching biology to 12-16 year old pupils. Indicating age groups has proven to be an effective mean in overcoming country specific ways of specifying a level of education.

\section{Secondary school teacher education in Flanders}

This paragraph's heading is not a synonym of teacher education in Belgium. Such education does not exist. Be it a small country compared to France $\left(30.528 \mathrm{~km}^{2}\right.$ versus $670.922 \mathrm{~km}^{2}$ (Guadeloupe included), or about 22 times smaller (4)), Belgium has three times as many Ministries of Education compared to France, one for each of the three linguistic communities (Dutch, French and German). Teacher education in these three communities is organised differently. This article only focuses on the situation in Flanders.

In Flanders, teacher education is organised at different levels, i.e. at Bachelor level, at Master level and in Centres for Adult Education. Since 2007, two teacher education programmes exist, named integrated teacher education and specific teacher education.

Integrated teacher education programmes are offered by university colleges and lead to a degree of Bachelor in education in kleuteronderwijs (nursery), primary and 'lower' secondary education (pupils aged 12-16), respectively. Students holding a diploma of secondary education can attend these teacher education programmes, which last 3 years and comprise 180 European Credits, including 45 European Credits for the practical component. In the 'secondary education' programme, students choose 2 teaching subjects. Biology can be combined by subjects such as geography, history, home economics, arts, physical education, and etcetera. 
Students who have already obtained a diploma of higher education (e.g. a master degree in biology) can become a teacher for 'upper' secondary education (pupils aged 16-18) by following a specific teacher education programme where they get additional pedagogical/teaching training. This programme comprises 60 European Credit of which 30 European Credits are specifically allocated to teaching practice. The holder of a master in biology and a diploma of the specific teacher education programme is allowed to teach several subjects at upper secondary education level, i.e. biology, chemistry, physics.

The specific teacher education programme can also be followed by persons that obtained a diploma of adult education (or who are following such education leading to a diploma) or by persons who have relevant professional experience. These programmes are often organised by Centra voor Volwassenenonderwijs (CVOs, Centres for Adult Education).

The content of all teacher education programmes in Flanders, be it nursery, primary, lower or upper secondary teacher education, is chosen by the school of education which the student attends. The school's freedom however should always reflects both the Flemish Ministry of Education's subject specific final objectives (e.g. of biology) in secondary schools, as well as the basic teacher competencies. There are ten basic teacher competencies described (5), the competencies describe the roles of the teacher: (I) as facilitator of learning and developmental processes, (II) as educator, (III) as content expert, (IV) as organiser, (V) as innovator and researcher, (VI) as partner of parents/guardians, (VII) as member of the school, (VIII) as partner of external organisations, (IX) as member of the education community, and (X) as a culture participant.

Secondary school biology teachers that attended an initial teacher education programme will teach biology to pupils aged 12-16 (or 18 in vocational secondary schools). Table 2 mentions for pupils in general secondary schools in Flanders what they will learn during 1-2 hours per week in biology classes (for the 12-13 year old pupils since September 2010 due to a curriculum revision biology has been renamed natural sciences).

From table 2 it becomes clear that 12 year old learn a lot about their own body functions, which regulation processes are explained when they are 14. More general natural sciences' topics are dealt with while they are 12-13. The curriculum for 12 and 15 year old pupils strongly emphasizes ecology and the environment. 


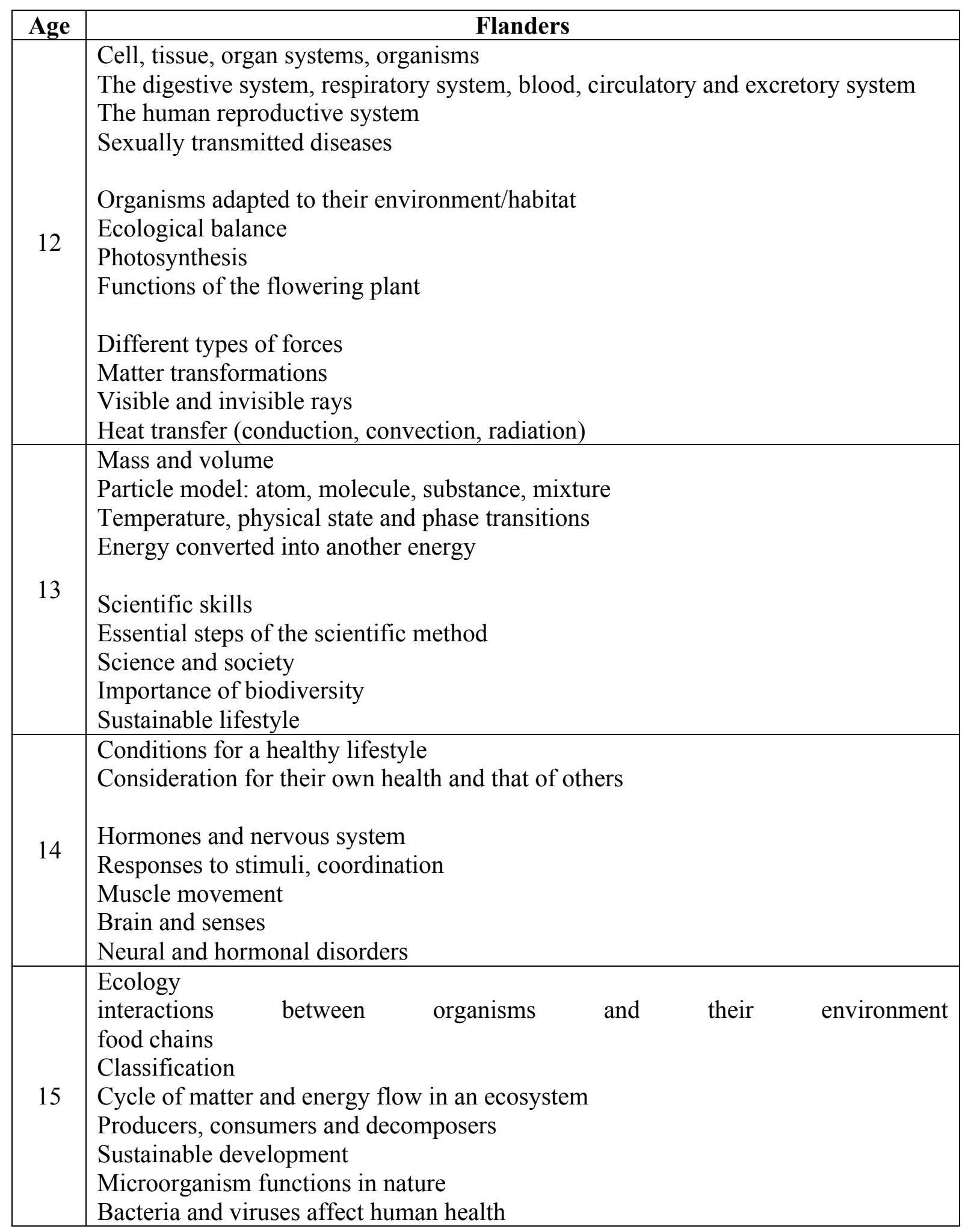

Table 2 : Biology/Natural Sciences curriculum for pupils aged 12-15 in general secondary schools in Flanders (6) 


\section{Secondary school teacher education in France}

All teacher education for all levels of primary and secondary education (general, technological, vocational and specialised level) is provided for at Instituts Universitaires de Formation des Maîtres (IUFM of University Institutes of Teacher Education). The status of the IUFM has been modified by the French law of 2005 concerning the programme for the future of the school (loi d'orientation et de programme pour l'avenir de l'école) (7). Gradually all IUFMs have been integrated as schools of education within universities and are supervised by the French Ministry of Education. A new reform in force since 01/09/2010 on the recruitment and training of teachers will affect the training mission of the IUFM. Both IUFM and universities are currently working on new study programmes as proposed by the reform (8).

Up to the 2010 reform at least 3 years of post baccalaureate (Bachelor) studies were required to be accepted by an IUFM. From 2011 onwards students are required to hold a master degree in order to be able to participate in a teacher education programme at IUFM. One of the reform's objectives was to raise the level of recruitment and improving the quality of training.

The number of students accepted by an IUFM depends on the teaching subject envisaged. Being accepted also depends as on the capacity of the student. The latter is measured through evaluation of the students, through a combination of results on a written test and an oral Interview.

The secondary school teacher education at the IUFM lasts two years. In the first year at IUFM students are being prepared for a competitive examination in the teaching subject of their choice. The teaching subjects of biology is incorporated into the subject Sciences de la Vie et de la Terre (= SVT, Life and Earth Sciences). During on year of theoretical training the student is prepared for central examinations organised in Paris by the Ministry of Education. Students passing the examinations successfully obtain the Certificat d'Aptitude au Professorat de l'Enseignement du Second degree (CAPES, teacher education certificate for secondary school level). Other levels of secondary school education require other certificats: CAPEPS = Certificat d'Aptitude au Professorat de lÉducation Physique et Sportive (teacher education certificate for physical education and sport) ; CAPLP = Certificat d'Aptitude au Professorat des Lycées Professionnels (teacher education certificate for vocational education) ; or CAPET = Certificat d'Aptitude au Professorat de l'Enseignement Technologique (teacher education certificate for technological education) (9). Besides these certificates holders of a masters degree can opt for taking part in a more difficult and more prestigious examination: the agrégation (aggregation).

Students that obtained a certificate/aggregation will be allowed to enter the second year of training at the IUFM, which is more professionally oriented and includes several "stages", periods of practical teaching experience of at least 108 hours in total. During their practice in school, teacher students also attend classes of mentoring and coaching. Students are allocated to a school for their internship. (10)

Upon graduation holders of the teacher education diploma will be allocated to a secondary school for one year by the Ministry of Education anywhere in France (!). Secondary school in France is divided into collège (ages 11-15) and lycée (ages 16-18). Biology teachers that completed 2 years at the IUFM successfully and have obtained the CAPES or the aggregation are entitled to teach biology both the collège and the lycée. Holders of an aggregation have to 
teach less hours per week (15 instead of 18) and are better paid than holders of the CAPES. As teachers have the status of civil servants the first year in education is seen as a sort of internship, when successfully completed the teacher becomes a permanent civil servant. Chances of being transferred to a school in ones region of origin, increases with the number of years of being a teacher.

In France the school subjects of biology and earth sciences have always been linked in secondary school teaching. As mentioned above the school subject is called "Sciences de la Vie et de la Terre" (= SVT, Life and Earth Sciences) in which biology represents approximately $2 / 3$ of the content. Therefore teacher education courses involve both biology and earth sciences. Secondary school biology teachers that completed their studies at IUFM specializing in SVT will teach SVT to pupils aged 11-18. Table 3 mentions the SVT curriculum for pupils in lower secondary schools (collège) in France. In collège SVT is taught during 1,5 hours per week.

\begin{tabular}{|l|l|}
\hline Age & \multicolumn{1}{c|}{ France } \\
\hline 11 & $\begin{array}{l}\text { Characteristics of the surrounding environment and distribution of living beings } \\
\text { The population of an environment } \\
\text { Origin of the matter of living things } \\
\text { Practices in human nutrition } \\
\text { Diversity, kinship and unity of living }\end{array}$ \\
\hline 12 & $\begin{array}{l}\text { The production of energy needed for functioning of organs } \\
\text { The functioning of the respiratory system } \\
\text { Digesting of food and intake of nutrients } \\
\text { Excretion of nutrition } \\
\text { The role of blood flow in the body } \\
\text { External geology: landscape evolution }\end{array}$ \\
\hline 13 & $\begin{array}{l}\text { Internal activity of the globe } \\
\text { Sexual reproduction and maintenance of species } \\
\text { Transmission of human life } \\
\text { Relations between organisms }\end{array}$ \\
\hline 14 & $\begin{array}{l}\text { Diversity and unity of human beings } \\
\text { Evolution of living organisms and earth history } \\
\text { Risk of infection and protection of the organism } \\
\text { Human responsibility towards health and environment }\end{array}$ \\
\hline
\end{tabular}

Table 3 : Life and Earth Sciences curriculum for pupils aged 12-15 in lower secondary schools (collège) in France $(11,12)$

From table 3 it becomes clear that the main objectives of biology teaching are understanding how the human organism operates and the organisation of the environment. At the age of 15 it is expected that each pupil has acquired the essential knowledge to ensure an understanding of the living world, the earth, nature and the changes induced by human activity. Furthermore pupils should be capable and have the appropriate attitude to use this knowledge and make justified choices in adult life. 


\section{Comparing biology teacher education in Flanders and in France}

During the LLP-ERASMUS Staff Mobility Teaching Assignment at the IUFM in Guadeloupe it became clear that not only the education systems of Flanders and France differs, but also that the biology subject content in secondary education differs as does the biology teacher education.

A visual representation of the Flemish and French education system, taken from the European Commission's Eurydice database, elaborates that secondary education in Flanders starts at the age of 12, in France at the age of 11. The levels of secondary education (general or more vocational) start to differ in Flanders for pupils aged 14, at the age of 15 in France.

From this visual representation of the education systems, it seems that the organisation of secondary education after the age of 14 is more complex in Flanders (a European region with about 6 million inhabitants) than in France (a country with more than 62 million inhabitants). Flemish pupils can choose between algemeen / technisch / kunst / beroeps (= general / technical / art / vocational) secondary education, French pupils have the choice between a lycée général \& technologique (general \& technological) or a lycée professionnel (vocational) secondary school.

\section{Belgium - Flemish Community}

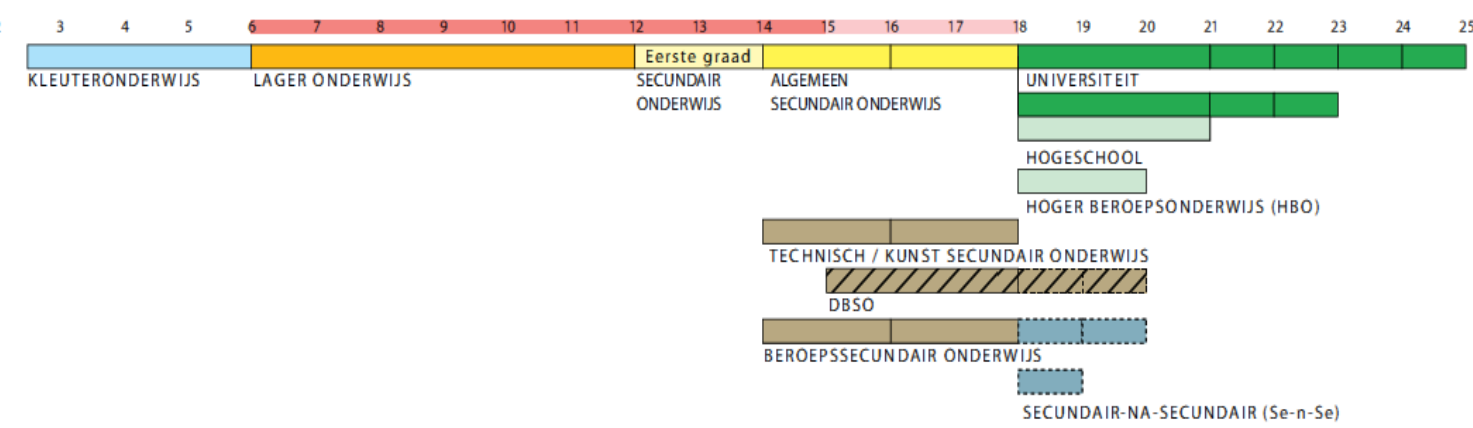

\section{France}

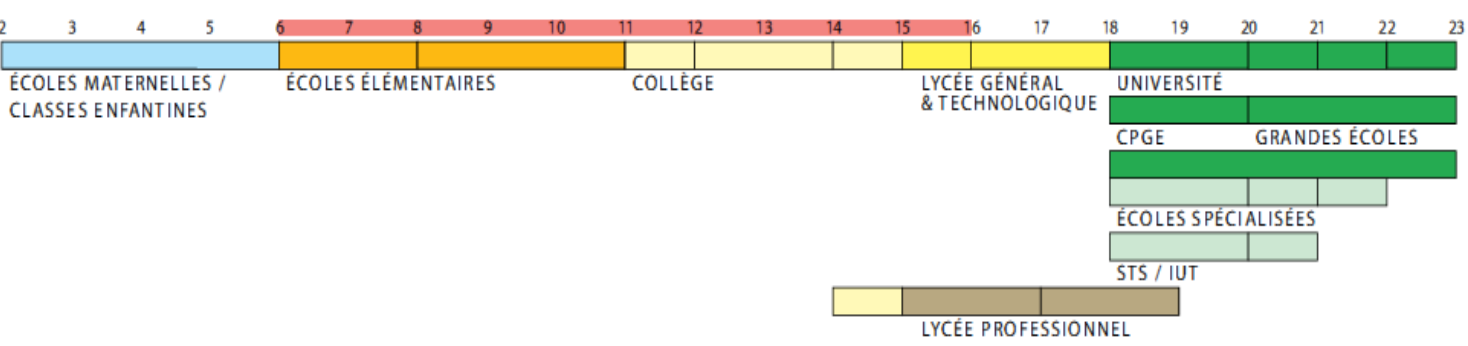

Figure 1 : A visual representation of the Flemish and French education system, taken from the European Commission's Eurydice database (13)

The secondary school subject of biology has different names in Flanders (natuurwetenschappen (= natural sciences for pupils aged 12-13) and biologie (= biology for pupils aged 14-15)) and in France (Sciences de la Vie et de la Terre (= SVT, Life and Earth Sciences for pupils aged 11-14)). 


\begin{tabular}{|c|c|c|}
\hline Age & Flanders & France \\
\hline 11 & & $\begin{array}{l}\text { Characteristics of the surrounding } \\
\text { environment and distribution of } \\
\text { living beings } \\
\text { The population of an environment } \\
\text { Origin of the matter of living things } \\
\text { Practices in human nutrition } \\
\text { Diversity, kinship and unity of living }\end{array}$ \\
\hline 12 & $\begin{array}{l}\text { Cell, tissue, organ systems, organisms } \\
\text { The digestive system, respiratory system, blood, } \\
\text { circulatory and excretory system } \\
\text { The human reproductive system } \\
\text { Sexually transmitted diseases } \\
\text { Organisms adapted to their environment/habitat } \\
\text { Ecological balance } \\
\text { Photosynthesis } \\
\text { Functions of the flowering plant } \\
\text { Different types of forces } \\
\text { Matter transformations } \\
\text { Visible and invisible rays } \\
\text { Heat transfer (conduction, convection, radiation) }\end{array}$ & $\begin{array}{l}\text { The production of energy needed for } \\
\text { functioning of organs } \\
\text { The functioning of the respiratory } \\
\text { system } \\
\text { Digesting of food and intake of } \\
\text { nutrients } \\
\text { Excretion of nutrition } \\
\text { The role of blood flow in the body } \\
\text { External geology: landscape } \\
\text { evolution }\end{array}$ \\
\hline 13 & $\begin{array}{l}\text { Mass and volume } \\
\text { Particle model: atom, molecule, substance, mixture } \\
\text { Temperature, physical state and phase transitions } \\
\text { Energy converted into another energy } \\
\text { Scientific skills } \\
\text { Essential steps of the scientific method } \\
\text { Science and society } \\
\text { Importance of biodiversity } \\
\text { Sustainable lifestyle }\end{array}$ & $\begin{array}{l}\text { Internal activity of the globe } \\
\text { Sexual reproduction and maintenance } \\
\text { of species } \\
\text { Transmission of human life } \\
\text { Relations between organisms }\end{array}$ \\
\hline 14 & $\begin{array}{l}\text { Conditions for a healthy lifestyle } \\
\text { Consideration for their own health and that of } \\
\text { others } \\
\text { Hormones and nervous system } \\
\text { Responses to stimuli, coordination } \\
\text { Muscle movement } \\
\text { Brain and senses } \\
\text { Neural and hormonal disorders }\end{array}$ & $\begin{array}{l}\text { Diversity and unity of human beings } \\
\text { Evolution of living organisms and } \\
\text { earth history } \\
\text { Risk of infection and protection of } \\
\text { the organism } \\
\text { Human responsibility towards } \\
\text { health and environment }\end{array}$ \\
\hline 15 & $\begin{array}{l}\text { Ecology } \\
\text { Interactions between organisms and their } \\
\text { environment } \\
\text { Food chains } \\
\text { Classification } \\
\text { Cycle of matter and energy flow in an ecosystem } \\
\text { Producers, consumers and decomposers } \\
\text { Sustainable development } \\
\text { Microorganism functions in nature } \\
\text { Bacteria and viruses affect human health }\end{array}$ & \\
\hline
\end{tabular}

Table 4 : Comparison of the subject content in the "biology" curricula of Flanders and France. Similarities have been highlighted in bold print 
In Flanders as well as in France the more biological content in both curricula stresses on the understanding of the functioning of the human organism and of the environment. Both curricula have some identical topics taught at the same age, i.e. digestive system, respiratory system, circulatory and excretory system at the age of 12 and human responsibility towards health at the age of 13. Nevertheless, many other identical topics are taught at different ages (e.g. reproduction). In Flanders the curriculum represents more core natural sciences (i.e. chemistry, physics), whereas the French curriculum relates more to earth sciences. Also interesting to note is that some topics are unique in both the Flemish and the French curricula.

When it comes to teacher education more differences than similarities have been noticed. The most striking differences are the pre-requisites to become a teacher, the study load of the teacher education and the kinds of institutions involved in teacher education.

In Flanders holders of a secondary school diploma can decide to become a teacher. In France a Bachelors degree used to be required, recently this was 'upgraded' to a Masters degree.

In Flanders teacher education lasts either 180 European Credits at Bachelors level for teachers in nursery, primary and lower secondary schools or 60 European Credits at Masters level for teachers in upper secondary schools. In France all teachers are trained at University integrated institutes, i.e. IUFM where they have to attend a 120 European Credits teacher education programme at Masters level. In the future all biology teachers in French secondary schools will have had the same pre-service teacher education, in Flanders two differently trained biology teachers remain to exist.

\section{Literature and Sources}

Belgisch Staatsblad (2008). Bijlage bij het besluit van de Vlaamse Regering van 5 oktober 2007 betreffende de basiscompetenties van de leraren, p.1594-1631. Brussels. (5)

Belgisch Staatsblad (2009). Besluit van de Vlaamse Regering betreffende de eindtermen en ontwikkelingsdoelen in het basis- en secundair onderwijs, Brussels. (6)

Bulletin Officiel (2005). La loi $\mathrm{n}^{\circ}$ 2005-380 du 23 avril 2005 d'orientation et de programme pour l'avenir de l'École, 18, Paris. (7)

European Commission (2010). Online

http://eacea.ec.europa.eu/education/eurydice/documents/eurybase/national_summary_sh eets/047_FR_EN.pdf, consulted May 6th 2010. (9)

European Commission (2010). Online

http://eacea.ec.europa.eu/education/eurydice/documents/tools/108EN.pdf, consulted

May 6th 2010. (13)

European Commission (2010). Online http://ec.europa.eu/education/lifelong-learning-

programme/doc1208_en.htm, consulted May $6^{\text {th }} 2010$. (1)

European Commission (2010). Online

http://ec.europa.eu/education/erasmus/doc/stat/table3.pdf, consulted May $6^{\text {th }} 2010$. (2)

European Commission (2010). Online http://eur-

lex.europa.eu/LexUriServ/LexUriServ.do?uri=CELEX:32001D0822:EN:HTML, consulted May $6^{\text {th }} 2010$. (3)

Journal Officiel (2009). Le cadrage national des concours (les arrêtés du 28 décembre 2009), Paris. (8)

Mazoyer, E. (2009). SVT, sciences de la vie et de la Terre 3e: programme. Paris : Belin. (11) 
Ministère de l'Éducation nationale (2010). Online http://media.education.gouv.fr/file/special_6/52/9/Programme_SVT_33529.pdf, consulted May 6th 2010. (12)

Ministère de l'Éducation nationale (2010). Online http://www.education.gouv.fr/cid42647/mene0917847c.html, consulted May 6th 2010. (10)

Ros, E. (2002). De Wereld, atlas en landenlexicon. Tielt : Uitgeverij Lannoo. (4) 